\title{
The Implementation of Indonesia's State Obligations in relation to the Rights of Persons with Disabilities in Aviation
}

\author{
Adya Paramita Prabandari ${ }^{1}$, Rahayu $^{2}$, Elfia Farida ${ }^{3}$ \\ \{adyapprabandari@gmail.com ${ }^{1}$, rahayu@lecturer.undip.ac.id ${ }^{2}$, elfiaundip@gmail.com ${ }^{3}$ \} \\ Faculty of Law, Universitas Diponegoro, Semarang, Indonesia ${ }^{1}$, Faculty of Law, Universitas \\ Diponegoro, Semarang, Indonesia ${ }^{2}$, Faculty of Law, Universitas Diponegoro, Semarang, Indonesia ${ }^{3}$
}

\begin{abstract}
State is the main responsible entity in respecting, fulfilling, and protecting human rights, at least for its citizen and other people in its territory. Indonesia, as a country based on Pancasila and the 1945 Constitution of the Republic of Indonesia that respects and upholds human dignity, should give recognition and protection of human rights for all Indonesian citizens. This of course applies in every aspect of life, including in the civil aviation. This paper will describe the implementation of Indonesia's state obligations related to the rights of persons with disabilities in Aviation.
\end{abstract}

Keywords: state obligations, rights of persons with disabilities, aviation

\section{Introduction}

The term "human rights" began to be used and received great attention from the international community after the terrible events that occurred in World War II. This term replaced the term "natural rights", and also "the rights of men" that became a matter of great controversy.[1] Members of the UN pledge to start taking various measures in order to respect and protect human rights and fundamental freedoms for all. [2] This step began with the adoption of the UDHR on December 10, 1948 by the UN. This was followed by the adoption of various international instruments including the ICCPR and the ICESCR in 1966; the International Convention against Torture and Other Cruel, Inhuman and Degrading Treatment or Punishment (CAT) in 1984; and the Convention on the Rights of Persons with Disabilities (CRPD) in 2006. The adoption of these various international instruments shows the goodwill of the international community to respect and protect human rights, including for members of vulnerable groups such as persons with disabilities.

The CRPD was "a result of the recognition that discrimination against persons as a result of disability is unacceptable and that there is a need to promote and protect the fundamental human rights of persons with disabilities".[3] The Preamble of CRPD states in the item (v) that in order for persons with disabilities to fully enjoy all human rights and fundamental freedoms, it is very important to consider the accessibility in every environment and every aspect of life, i.e. physical and social environment. This is further stated in Article 9 (1) of the CRPD on the Accessibility of persons with disabilities that States Parties shall take appropriate measures to ensure that they have access on equal basis with others in every environment and every aspect of life, including facilities and services provide for public transportation. This article clearly states the state's obligation to ensure the fulfillment of the accessibility rights of persons with 
disabilities, which is certainly in line with the state's obligations as a duty bearer in respecting, fulfilling and protecting human rights.

Likewise, Indonesia as one of the countries that has ratified the CRPD with the Law Number 19 of 2011 on the Ratification of the CRPD on November 10, 2011. This action certainly brings consequences for Indonesia in the form of the obligation to comply with and implement CPRD in its national law.

The aim of this study is to find out the implementation of the Indonesia's state obligations in relation to the Rights of Persons with Disabilities particularly with regard to the accessibility rights of persons with disabilities in civil aviation.

\section{Method}

The research method used in this research is the Normative Juridical method "which is carried out by examining library materials which are secondary data".[4] This study combines two approaches, namely the statute approach and the conceptual approach.[5] The data used and analyzed in this study is secondary data consisting of legal materials and non-legal materials, which are collected using the literature study and document study methods. [6] The data obtained in this study were then selected and arranged systematically for further analysis and elaboration using qualitative analysis methods. [7]

\section{Results}

\subsection{The Concept of State Obligations related to Human Rights}

Related to human rights, in principle, the state as a duty bearer, has obligations to respect, to fulfill and to protect the human rights of its citizens.[8] The obligation to respect means that the state has an obligation to refrain from interfering in any way, except on legal grounds (legitimate). States have to avoid any law or action that would result in a deprivation of access to rights. [9] The second is the obligation to fulfill which means that the state has an obligation to take legislative, administrative, judicial and practical measures necessary to ensure the fulfillment of human rights as widely as possible. While the obligation to protect is the obligation of the state to protect not only against violations committed by the state, but also from acts or violations committed by other non-state entities or parties that would interfere with these protection. [10]

\subsection{Persons with Disabilities}

Until now, there is no unity of opinion concerning the definition of disability due to its complexity and multidimensional. [11] In 1997, the UN defined disability as follows: function.

"Impairment: Any loss or abnormality of psychological, or anatomical structure or

Disability: Any restriction or lace (resulting from an impairment) of ability to perform an activity in the manner or within the range considered normal for a human being.

Handicap: A disadvantage for a given individual, resulting from an impairment or disability, that limits or prevents the fulfillment of a role that is normal, depending on age, sex, social and cultural factors, for that individual. 
Handicap is therefore a function of the relationship between disabled persons and their environment. It occurs when they encounter cultural, physical or social barriers which prevent their access to the various systems of society that are available to other citizens. Thus, handicap is the loss or limitation of opportunities to take part in the life of the community on an equal level with others."[12][13]

Then in December 13, 2006, the General Assembly of the UN adopted the CRPD. This is the first legally binding instrument on the issue of disability[14] and applies to all person with disabilities, including "those who have long-term physical, mental, intellectual or sensory impairments". The purpose of the convention is clearly stated in Article 1 "to promote, protect and ensure the full and equal enjoyment of all human rights and fundamental freedoms by all persons with disabilities, and to promote respect for their inherent dignity". The CRPD describes the various rights held by persons with disabilities which must be respected, fulfilled and protected by the state, along with the rights of other people.

\section{Discussion}

Human rights make the state as the main legal subject, because the state is the main responsible entity in respecting, fulfilling, and protecting human rights, at least for its citizen and other people in its territory.

Indonesia, as a country based on Pancasila and the 1945 Constitution of the Republic of Indonesia that respects and upholds human dignity, should give recognition and protection of human rights for all Indonesian citizens. This is in accordance with one of the objectives of the Republic of Indonesia as stated in Paragraph 4 of the Preamble of the 1945 Constitution, namely "... to form an Indonesian State Government which shall protect the whole Indonesian nation and the entire native land of Indonesia, ...". This objective then further described in the articles of the 1945 Constitution namely in:

Article 28G (1)

"Every person shall be entitled to protection of his/her own person, family, honor, dignity, and property under his/her control, as well as be entitled to feel secure and be entitled to protection against threat of fear to do or omit to do something being his/her fundamental right" Article $28 \mathrm{H}(2)$

"Every person is entitled to receive ease and special treatment in order to obtain the same opportunity and benefit in order to achieve equality and justice."

Article 28I (2)

"Every person is entitled to be free from discriminative treatment on whatsoever basis and is entitled to acquire protection against such discriminative treatment".

The rules in the articles mentioned above clearly bring obligations for Indonesia which has been very emphatically stated in Article 28I (4) that "The protection, advancement, enforcement and fulfillment of human rights shall be the responsibility of the state, particularly the government". These obligations, among others, was later manifested in the form of enacting Law Number 39 of 1999 concerning Human Rights (further referred as Human Rights Law), that then followed by the enactment of various laws concerning the protection of human rights in various fields in Indonesia. One of the them that has been ratified by Indonesia is the CRPD with the Law Number 19 of 2011 on the Ratification of the Convention on the Rights of Persons with Disabilities on November 10, 2011. This is a step forward by the Indonesian government in recognizing the importance of protection and fulfillment as well as special attention for 
persons with disabilities, as well as in accordance with the Pacta Sunt Servanda principle that Indonesia is obliged to implement an international agreement that has been ratified in good faith.[15] This is reinforced by Article 7 (2) of the Human Rights Law, which states that "The provisions of international law that have been accepted by the State of the Republic of Indonesia concerning human rights become national law".

In carrying out these obligations, the Government of Indonesia has firmly stated in Article 5 (3) of the Human Rights Law that "All members of disadvantaged groups in society, such as children, the poor, and the disabled are entitled to greater protection of human rights", and also in Article 41 (2) that "The disabled, elderly, pregnant women and children have a right to special facilities and treatment". The government then established Law Number 8 of 2016 concerning Persons with Disabilities which also replaces Law Number 4 of 1997 concerning Persons with Disabilities who are considered no longer in accordance with the paradigm of the needs of persons with disabilities, as well as an adoption of the existing rules in CRPD. This is a proof of Indonesia's seriousness in carrying out its obligations to respect, fulfill and protect the human rights of persons with disabilities.

In the transportation sector, persons with disabilities are guaranteed accessibility rights in Law Number 8 of 2016, particularly in Article 9 (1), Article 18 and Article 19. Furthermore in the air transportation sector, the accessibility rights are guaranteed in Law Number 1 of 2009 concerning Aviation (in Article 118 (1) (e), Article 134, and Article 239), Minister of Transportation Regulation 38 of 2015 on the Domestic Air Passenger Service Standards, Minister of Transportation Regulation No. PM 77 of 2015 on the Standardization and Certification of Airport Facilities, and Minister of Transportation Regulation 98 of 2017 on the Providing Accessibility to Passenger Services for Public Transportation Services for Service Users with Special Needs.

\section{Conclusion}

Related to human rights, the state has a position as a duty bearer, which has obligations to respect, to fulfill and to protect the human rights of its citizens. So it is with Indonesia, as a country based on Pancasila and the 1945 Constitution of the Republic of Indonesia that respects and upholds human dignity, should really carry out the obligations to respect, fulfill and protect human rights, including the rights of persons with disabilities in every aspect of life, including in the aviation sector. The implementation of Indonesia's state obligations in relation to the rights of persons with disabilities in aviation appears in the following ways:

a. The enactment of various laws and regulations concerning aviation and the standardization of facilities for service users with special needs (aka. Persons with disabilities);

b. The construction of various facilities according to predetermined standards to be used in serving persons with disabilities who will travel by air, both building facilities at the airports, as well as equipping aircrafts with various necessary facilities; and

c. Provide training to officers involved in various stages and processes of air transportation, starting at the airport before embarkation, during the flight, until the passenger with disability arrives at their destination safely.

\section{Acknowledgments}


Acknowledgments. The author is very grateful to the Faculty of Law, Universitas Diponegoro, for all the support and financial assistance from the 2020 fiscal year research funding. And also to Prof. Dr. Rahayu, SH., M.Hum. and Elfia Farida, SH., M.Hum. as research fellows for the teamwork and endless support during this research.

\section{References}

[1] B. H. Weston, "Human Rights," Hum. Rights Q., pp. 257-283, 1984.

[2] D. L. Sills, Ed., International Encyclopaedia of Social Sciences. New York: The Macmillan Company and the Free Press, 1968.

[3] Y. Basson, "State Obligations in International Law related to the Right to an Adequate Standard of Living for Persons with Disabilities," Law Democr. Dev., vol. 21, pp. 68-83, 2017.

[4] R. H. Soemitro, Metodologi Penelitian Hukum dan Jurimetri. Jakarta: Ghalia Indonesia, 1990.

[5] J. Ibrahim, Teori \& Metodologi Penelitian Hukum Normatif. Malang: Bayumedia Publishing, 2006.

[6] P. M. Marzuki, Penelitian Hukum, 1st ed. Jakarta: Kencana, 2005.

[7] M. F. ND and Y. Achmad, Dualisme Penelitian Hukum Normatif dan Empiris. Yogyakarta: Pustaka Pelajar, 2010.

[8] M. Nowak, Introduction to the International Human Rights Regime. Leiden: Martinus Nijhoff, 2003.

[9] I. T. Winkler, "Respect, Protect, Fulfill: The Implementation of the Human Right to Water in South Africe," in Water Governance in Motion: Towards Socially and Environmentally Sustainable Water Laws, P. Cullet, A. Gowlland-Gualtieri, R. Madhav, and U. Ramanathan, Eds. London: Foundation Books, 2010, pp. 415-444.

[10] Rahayu, Hukum Hak Asasi Manusia. Semarang: Badan Penerbit Universitas Diponegoro, 2015.

[11] S. Mitra, "The Capability Approach and Disability," J. Disabil. Policy Stud., vol. 16, no. 4, pp. 236-247, 2006.

[12] United Nations, "Decade of Disabled Persons 1983-1992: World Programme of Action concerning Disabled Persons 3," 1997.

[13] D. Kaplan, "The Definition of Disability: Perspective of the Disability Community," J. Heal. Care Law Policy, vol. 3, no. 2, pp. 352-364, 2000.

[14] K. Kazou, "Analysing the Definition of Disability in the UN Convention on the Rights of Persons with Disabilities: Is It Really Based on a 'Social Model' Approach?," Int. J. Ment. Heal. Capacit. Law, vol. 23, pp. 25-48, 2017.

[15] E. Pratomo, Hukum Perjanjian Internasional: Dinamika dan Tinjauan Kritis terhadap Politik Hukum Indonesia. Jakarta: Elex Media Komputindo, 2016. 